\title{
A NEW STAGE IN THE UPPER CENOZOIC OF SOUTHERN SOUTH AMERICA
}

CIONE, Alberto L.; TONNI, Eduardo P., Dept. Cientifico Faleontologia Vertebrados, Museo de La Plata, 1900

Le Fiatá, Argentina.

Former workers developed in South America a chronostratigraphic system not essentially different to that of European stage/age system. However, the authors of this paper believe that accurate biostratigraphic studies have to be done in southern South America for establishing the precise boundary stratotypes of most stage'ages. A new South American Upper Cenozoic continental stage/age is recognized. The stratotype is located in the fossiliferous southeastern Buenos Aires. Frovince marine cliffs between Mar del Flata and Miramar. The cutcrops in the area are the best continental representation of Plio-Pleistocene times in South America. It is younger than Chapadmalalan and older thari Ensenadan and replaces the "Uquian". We consider that the "Uquian" ac tually emcopasses Chapadmalalan and Ensenadan times. The lquia outcrops are here considered inadequate as stratotype especially by the dearth of micromirmals, the relatively poor fossil record and the comr.j.atively iriadequate geographic location. Tire new stage would be correlated with the Gause. Ehron and possibly with the lower Matuyama Chrow. The lower boundary is tentatively stated. For so doing, a biostratigraphic scheme is propo:-d. This lower boundary approximately corresponds to the base of the Barranca de los Lobos "Formation" of Kraglievich (1952) and a new (unpublished) unconformity bounded unit (Zarate, 1989). Some tasa that apparently ranges from the base are candidates to define it after a detailed biostratigraphic study.

Additionally, a different timing for the arrival of North American mammals to southern South America is given. 